\title{
Recapture and condition of pond-reared, and hatchery-reared 1+ European grayling stocked in addition to wild conspecifics in a small river
}

\author{
J. Turek ${ }^{(1), \star}$, P. Horký(2), V. Žlábek ${ }^{(1)}$, J. Velíšek ${ }^{(1)}$, O. Slavík(2), T. Randák ${ }^{(1)}$ \\ Received January 18, 2012 \\ Revised April 4, 2012 \\ Accepted May 14, 2012
}

\section{ABSTRACT}

Key-words: The relative performance of European grayling Thymallus thymallus reared Thymallus thymallus, river management, stocking, recapture, grayling in a hatchery on commercial dry feed or in a pond with natural food and their wild conspecifics, was assessed through recapture of tagged fish 5 months after their release into the Blanice River, Czech Republic. Oneyear old pond and hatchery reared fish from a resident broodstock were marked using Visible Implant Elastomer tags and released into $3 \mathrm{sec}-$ tions of river in May 2006. Wild one-year-old grayling were also tagged in these sections on the same days. The ratio of hatchery reared, pond reared, and wild fish was 1:1:1 in all sections. The recapture rate (hatchery $14.9 \%$, pond $22.1 \%$, and wild $51.3 \%$ ) and site fidelity (hatchery $7.8 \%$, pond $13.0 \%$, and wild $35.1 \%$ ) were significantly different among groups. Wild fish had a higher probability of recapture upstream of their original section than did hatchery or pond reared fish. Pond rearing was superior to conventional hatchery rearing for subsequent stocking of $1+$ grayling in running water. Initially different mean condition factors were similar in all groups at recapture, suggesting adaptation of the artificially reared fish that remained in the river sections surveyed.

\section{RÉSUMÉ}

Recapture et condition d'ombres communs 1+ élevés en étang ou en pisciculture déversés en complément de congénères sauvages dans une petite rivière

\footnotetext{
Mots-clés :

Thymallus thymallus, gestion de rivière, alevinage, recapture, ombre
}

\begin{abstract}
La performance relative des ombres communs Thymallus thymallus élevés dans une écloserie avec des aliments secs commerciaux ou dans un étang avec des aliments naturels et de leurs congénères sauvages a été évaluée par la recapture de poissons marqués 5 mois après leur déversement dans la rivière Blanice, République tchèque. Des poissons d'un an issus de géniteurs sauvages, élevés en étang ou en écloserie, ont été marqués au moyen d'implants visibles élastomère et déversés en 3 sections de la rivière en mai 2006. Des ombres sauvages d'un an ont également été marqués dans ces sections ces mêmes jours. Le ratio de poissons d'élevage de pisciculture, d'étangs, et sauvages était dans toutes les sections 1:1:1. Le taux de recapture (écloserie de 14,9\%, 22,1\% étang, et sauvage $51,3 \%$ ) et la fidélité au site (écloserie de 7,8\%, d'étang de 13,0\%, et sauvage de
\end{abstract}

(1) University of South Bohemia in Ceské Budejovice, Faculty of Fisheries and Protection of Waters, South Bohemian Research Center of Aquaculture and Biodiversity of Hydrocenoses and Research Institute of Fish Culture and Hydrobiology, Zátiši 728/II, 38925 Vodnany, Czech Republic

(2) TGM - Water Research Institute, Podbabská 30, 16062 Praha 6, Czech Republic

^ Corresponding author: turek@frov.jcu.cz 
$35,1 \%$ ) étaient significativement différents entre les groupes. Les poissons sauvages avaient une plus forte probabilité de recapture en amont de leur section d'origine que les poissons d'écloserie ou d'étang. L'élevage en étang a été plus performant que l'élevage en écloserie classique pour le déversement d'ombres 1+ en rivière. Les différents facteurs de condition étaient les mêmes dans tous les groupes à la recapture, ce qui suggère une bonne adaptation des poissons élevés artificiellement qui restaient dans les sections des rivières étudiées.

\section{INTRODUCTION}

European grayling (Thymallus thymallus L.) is native to the Czech Republic (Balon, 1962; Lusk, 1975), but stocks in streams have been declining for many years. To re-establish threatened or extinct populations and expand the recreational fishery, hatchery-reared fish are commonly stocked. The success of stocking fish in natural waters depends on a variety of factors (Cowx, 1994). Hatchery-reared salmonids often have slower growth and lower fecundity and survival in the wild than do resident wild fish (Weber and Fausch, 2003). This may be partly due to stress effects of transportation (Jonsson et al., 1999; Finstad et al., 2003) and competition with wild residents, in which stocked fish generally lose conflicts - the so-called 'prior residence effect' (Rhodes and Quinn, 1998; Johnsson et al., 1999). Salonen and Peuhkuri (2004) observed lower levels of aggressive behaviour in hatchery strains of $T$. thymallus than in the wild strains at the age of $0+$ years, with the differences remaining to the age of $1+$, when the strains had been reared for a year under common hatchery conditions.

Rearing methods of fish stock is the critical factor in post-stocking behaviour and survival. Studies comparing wild, hatchery-reared, and pond-reared fish have shown that stocked fish have lower survival rates than wild fish (e.g. Miller, 1954; Vincent, 1960; Flick and Webster, 1964; Ersbak and Haase, 1983; Weiss and Schmutz, 1999). Huet, (1986) reported that fish reared in ponds were more suitable for stocking into natural waters, because pond-reared fish have learned to feed on natural prey. Carlstein (1997) found that $T$. thymallus reared in a natural pond showed higher post-stocking survival in a lake than fish reared in a conventional hatchery. Näslund (1992) observed higher post-stocking survival in pond-reared brown trout compared to hatchery-reared. Johnsen and Ugedal (1986), however, found no longterm differences in post-stocking feeding of hatchery-reared and wild brown trout. Similarly, no differences were found between pond- and hatchery-reared brown trout in post-stocking feeding or in recapture rate (Johnsen and Hesthagen, 1990; Johnsen and Ugedal, 1990). Turek et al. (2010a) reported a lower recapture rate of hatchery- and pond-reared $2+T$. thymallus compared to their wild conspecifics in a small stream, with no differences in growth between the groups six month post-stocking. Some further evidence from Magee and Byorth (1994) and Kaya and Jeanes (1995) showed a high degree of post-stocking downstream dispersal in juvenile Arctic grayling (Thymallus arcticus Pallas), similar to results reported for $T$. thymallus (Carlstein and Eriksson, 1996; Thorfve and Carlstein, 1998).

To improve the design of future restocking programmes, increased knowledge about poststocking performance of fish of varying ages and origins is needed. In the present study, pond and hatchery reared $1+T$. thymallus were released into three sections of the Blanice River in South Bohemia (Czech Republic). The aim of this study was to investigate the impact of the rearing technique on post-stocking growth and survival in this age category of T. thymallus and to compare performance of stocked fish with the resident conspecifics in the experimental sections.

\section{MATERIALS AND METHODS}

\section{> STUDY AREA}

The Blanice River in South Bohemia is $93 \mathrm{~km}$ long, with a drainage area of $860 \mathrm{~km}^{2}$. Three experimental sections of $150-190 \mathrm{~m}$ were located in a $5 \mathrm{~km}$ section of the river (river $\mathrm{km} \mathrm{53-58)}$ 


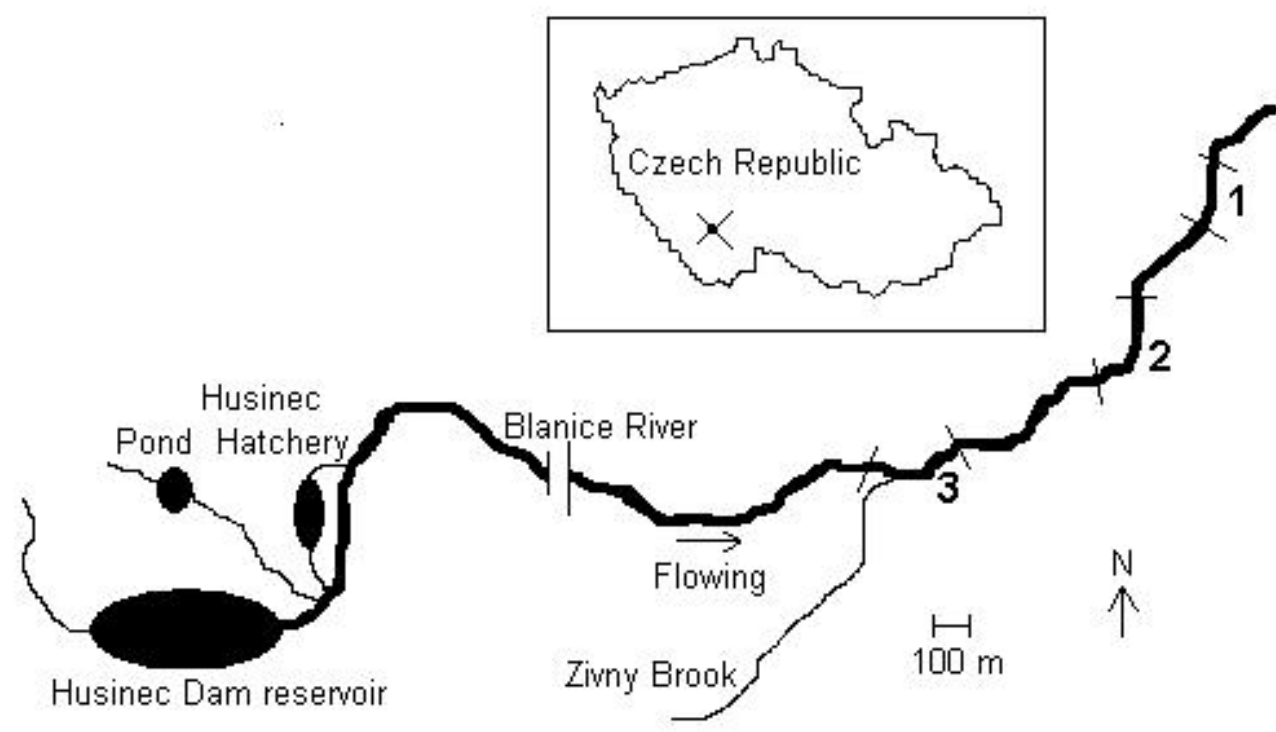

\section{Figure 1}

Schematic map showing the locations of experimental sections (1-3), hatchery and rearing pond.

in a protected area (fishing prohibited) downstream of the Husinec Dam reservoir (37 ha; $2.5 \times 10^{6} \mathrm{~m}^{3}$ ) (Figure 1). In this part of the river, water flow is characterized by wide seasonal fluctuations, with an annual mean flow of $3.5 \mathrm{~m}^{3} \cdot \mathrm{s}^{-1}$. During the experimental period (May-October 2006), the mean $( \pm \mathrm{SD})$ flow was $2.5 \pm 2.8 \mathrm{~m}^{3} \cdot \mathrm{s}^{-1}$, the mean $( \pm \mathrm{SD})$ water temperature was $12.5 \pm 3.5^{\circ} \mathrm{C}$, and $\mathrm{pH}$ was $7-7.8$. These values, and the water conductivity between $180-240 \mu \mathrm{S} \cdot \mathrm{cm}^{-1}$, are typical for the Blanice River in this season. The experimental sections are located in the countryside with broad-leaf trees and meadows at an elevation of about $500 \mathrm{~m}$ above sea level. The sections had natural gravel banks and were similar with respect to bottom substrate (gravel and stones), area (1200-1500 $\left.\mathrm{m}^{2}\right)$, and water velocity. Conditions were optimal for installation of pulsed-DC electrofishing units as barriers against escape of fish from the sections during electrofishing sampling. Depth range was $10-80 \mathrm{~cm}$ in all sections. The dominant fish species are brown trout (Salmo trutta $m$. fario L.) and grayling (Thymallus thymallus L.). Common sculpin (Cottus gobio), stoneloach (Barbatula barbatula L.), roach (Rutilus rutilus L.), and gudgeon (Gobio gobio L.) are caught occasionally.

\section{EXPERIMENTAL FISH}

All experimental fish were first generation progeny of wild broodstock resident in the Blanice River. One year-old $T$. thymallus originating from artificial spawning were reared from fingerling stage in ponds (pond fish) or in concrete tanks (hatchery fish). Pond fish were held in a natural pond of c. 1 ha supplied with water from a tributary of the Blanice River. Feeding was from naturally-occurring sources (zooplankton, benthos, terrestrial invertebrates). Hatchery fish were held in concrete tanks in the Husinec Hatchery (Czech Anglers' Union) supplied with water from the Blanice River and were fed on commercial dry food pellets. Both rearing facilities were situated c. 5-7 km upstream of the study area. 
Table I

Numbers of fish and their tagging in each experimental section at the beginning of experiment.

\begin{tabular}{ccccc}
\hline Section & Group & $\begin{array}{c}\text { Number of fish } \\
\text { stocked/measured }\end{array}$ & $\begin{array}{c}\text { Colour of } \\
\text { VIE tag }\end{array}$ & Position of VIE tag \\
\hline I & Wild & $44 / 44$ & Green & Left side of head \\
& Pond & $44 / 15$ & Red & (operculum and behind eye) \\
& Hatchery & $44 / 15$ & Pink & and left side of mandible \\
\hline \multirow{2}{*}{ II } & Wild & $58 / 58$ & Green & Right side of head \\
& Pond & $58 / 15$ & Red & (operculum and behind eye) \\
& Hatchery & $58 / 15$ & Pink & and right side of mandible \\
\hline \multirow{2}{*}{ III $\quad$ Wild } & $52 / 52$ & Green & Both side of head \\
& Pond & $52 / 15$ & Red & (operculum and behind eyes) \\
& Hatchery & $52 / 15$ & Pink & and middle of mandible \\
\hline
\end{tabular}

\section{$>$ SAMPLING}

Wild resident $T$. thymallus were captured by electrofishing. Sections were rigorously sampled twice on 15 May, 2006 using two back-pack pulsed-DC electrofishing units (FEG 1500, EFKOGermany). A further two pulsed-DC electrofishing units (FEG 3000, EFKO-Germany) were situated at the upper border of the section to prevent fish from escaping upstream. Captured wild T. thymallus of the target age group were anaesthetized with 2-phenoxy-ethanol $\left(0.2 \mathrm{~mL} \cdot \mathrm{L}^{-1}\right)$, measured (standard length $L_{S}, \mathrm{~cm}$ ), weighed (weight $W, g$ ), using the KERN Balance (type EMB 1200-1; max. $1200 \mathrm{~g}, d=0.1 \mathrm{~g}$ ) with plastic bowl and the measuring groove (accurate to $1 \mathrm{~mm}$ ), and tagged [visible implant elastomer (VIE), Northwest Marine Technology, Ltd., USA]. Fish were released near the point of capture after they fully recovered equilibrium and showed spontaneous swimming activity (c. 5 min after tagging). Population density of wild target fish was similar (approximately 0.05 individuals $\mathrm{m}^{-2}$ ) in all sections. Artificially reared $T$. thymallus were stocked (in 2-3 small groups) in the central part of sections on 16 May 2006. Water from the Blanice River was used for the transport in containers fitted with an oxygen injection system, and the duration of transport did not exceed $20 \mathrm{~min}$. The fish were tagged as with wild graylings before release. The VIE tags (different colours for hatchery-reared, pond-reared, and wild) were injected in small amounts underneath the transparent skin behind the eye, on the mandible, and the operculum. Fish were tagged on either the left or right side of their head or mid-mandible and behind both eyes to identify them according to section (Table I). During marking, all fish were anaesthetized with 2-Phenoxyethanol $\left(0.2 \mathrm{~mL} \cdot \mathrm{L}^{-1}\right)$. Forty-five fish from each cultured group (15 randomly chosen fish for each section) were measured $\left(L_{S}, \mathrm{~cm}\right)$ and weighed $(W, g)$.

The number of stocked fish from each group (hatchery and pond) was the same as the number of tagged wild $T$. thymallus of similar age in a given section. Consequently, the population of T. thymallus of this age category tripled in each experimental section. The total number of stocked fish was 154 individuals from each rearing method.

Five months after release (19-20 October 2006), the post-stocking performance of fish was evaluated. The fish were recaptured by the same method and with the same equipment described above. The experimental sections along with the sections between them, including approximately $2 \mathrm{~km}$ of the river upstream and downstream of the experimental area, were electrofished thoroughly. All tagged fish were identified, measured, and weighed and released near the point of capture. Initial and final Fulton's condition factor $\left(K=W L_{S}^{-3} \times 100\right)$ was determined for each recaptured fish. Site fidelity was defined as recapture of fish in the sections where they were originally released. Otherwise, the direction of their post-stocking dispersal (upstream or downstream) was recorded.

\section{> STATISTICAL ANALYSES}

All data were analysed with the aid of the statistical package SAS (version 9.1; SAS Institute Inc.). We applied an analysis of categorical repeat measures based on the generalized 
estimating equation (GEE) approach (Liang and Zeger, 1986) using the GENMOD procedure (SAS, version 9.1) with binomial distributions. In this study, the GENMOD procedure was designed to estimate the probability that fish (i) would be recaptured; (ii) would display site fidelity; (iii) would disperse downstream from the release section; and (iv) would disperse upstream from the release section. The explanatory variable 'origin of fish' was categorical, containing three classes (pond-reared fish, hatchery-reared fish, and wild fish).

Separate linear mixed models (LMM) were applied for the following dependent variables: weight (LMM I), standard length (LMM II), and condition factor K (LMM III and IV). LMM III was designed to compare the effect of fish origin before stocking and at recapture. LMM IV was designed to estimate the effect of fish origin combined with site fidelity at the end of the experiment. To randomize the effect of the river section, all analyses were performed using mixed model analysis, with river section as random factor, using PROC MIXED. The fixed effects were 'origin of fish' classes, 'time interval' (start, end), and 'site fidelity' (yes or no). The significance of each effect (including interactions) in the LMM was assessed by the F-test, with sequential dropping of the least significant effect, starting with a full model. The significance of each fixed effect in the mixed GLMM models was assessed by the $F$-test. Leastsquares-means (LSM; also referred to as 'adjusted means') were computed for each class, and differences between classes were tested by $t$-test. For multiple comparisons we used the Tukey-Kramer adjustment. The degrees of freedom were calculated using the Kenward-Roger method (Kenward and Roger, 1997).

\section{RESULTS}

Of the 462 grayling tagged, 136 (29.4\%) were recaptured five month after stocking. Wild fish showed a higher probability of being recaptured $\left(X^{2}=106.43\right.$; $d f .=2 ; P<0.001$; Figure 2a) and displaying site fidelity $\left(X^{2}=79.20 ; d f .=2 ; P<0.001\right.$; Figure $\left.2 b\right)$ than either of the two cultured fish groups. The probability of being captured and displaying site fidelity was higher in pond- than in hatchery-reared fish ( $P=0.0232 ; P=0.0364$, respectively). Wild fish also showed higher probability of being recaptured upstream of their original section than did reared fish $\left(X^{2}=33.99 ; d f .=2 ; P<0.001\right.$; Figure 2c). The difference between groups of cultured fish in upstream recapture was not significant. Fish origin did not influence downstream dispersal of tagged graylings.

The weight and length of fish increased significantly in all groups over the course of the experiment. Wild fish were heavier $\left(F_{5.378}=530.29, P<0.001\right)$ and longer $\left(F_{5.378}=766.69\right.$, $P<0.001$ ) than reared fish at the beginning as well as at the end of the experiment (Tables II and III). Lower $L_{S}$ of hatchery-reared fish in comparison with the pond-reared were recorded at the beginning of experiment only.

Wild fish showed higher condition factor $(K)$ than cultured at the beginning of the experiment $\left(F_{5.378}=51.68, P<0.001\right.$; Tables II and III), with significant differences between pond- and hatchery-reared. All groups of fish showed equal condition at the end of the experiment. This was the result of increased condition of reared fish along with decreased condition of wild fish. The wild and hatchery fish recaptured outside of their original section, regardless of direction, showed lower $K$ than fish exhibiting site fidelity $\left(F_{5.136}=4.04, P=0.002\right.$; Figure 3 ).

\section{DISCUSSION}

Lower recapture of pond and hatchery-reared T. thymallus released into a natural stream compared to their wild conspecifics corresponds with published reports of many researchers (e.g. Ersbak and Haase, 1983; Arias et al., 1995; Weiss and Schmutz, 1999) who also found lower post-stocking survival of artificially-reared fish. Competitive superiority of resident salmonids over introduced fish (Brännäs, 1995; Glova and Field-Dodgson, 1995), known as the 'prior residence effect' (Huntingford and DeLeaniz, 1997; Rhodes and Quinn, 1998), was a possible reason for lower recapture rate of artificially reared fish in comparison with the wild in the 

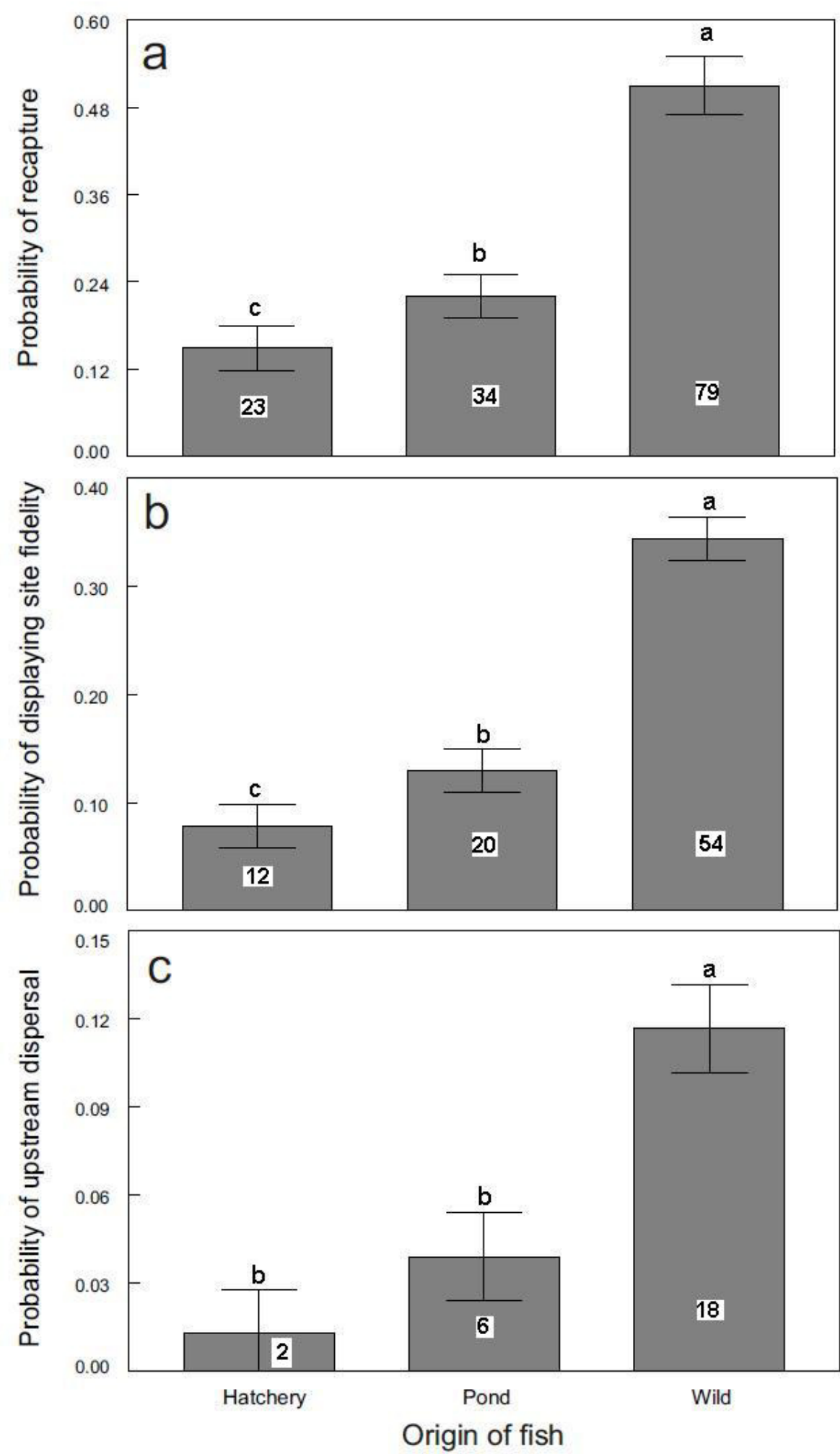

\section{Figure 2}

Predicted values (with confidence intervals) resulting from logistic regression model testing (a) probability of recapture, (b) displaying site fidelity and (c) upstream dispersal in relation to the origin of fish. Number of fish given is inside each column of the graph. Different letter above columns indicate a significant difference $(P<0.05)$. 


\section{Table II}

Post hoc Tukey results displaying mean $( \pm S D)$ standard length $\left(L_{S}\right)$, weight $(W)$, Fulton's condition factor $(K)$ of the tagged grayling.

\begin{tabular}{lcccc}
\hline Group & Number of fish & $L_{s}(\mathrm{~cm})$ & $W(\mathrm{~g})$ & ${ }^{*} K$ \\
\hline Wild & 154 & $15.0 \pm 1.2^{\mathrm{a}}$ & $46.5 \pm 11.9^{\mathrm{a}}$ & $1.37 \pm 0.23^{\mathrm{a}}$ \\
Pond & 45 & $12.1 \pm 1.0^{\mathrm{b}}$ & $18.4 \pm 5.6^{\mathrm{b}}$ & $1.02 \pm 0.21^{\mathrm{b}}$ \\
Hatchery & 45 & $10.9 \pm 0.9^{\mathrm{c}}$ & $11.4 \pm 5.3^{\mathrm{b}}$ & $0.85 \pm 0.23^{\mathrm{c}}$ \\
\hline
\end{tabular}

Within a column, different superscripts letters indicate a significant difference $(P<0.05)$. $\left.{ }^{*} K=\left(W L_{s}^{-3}\right) \times 100\right)$.

\section{Table III}

Post hoc Tukey results displaying mean $( \pm S D)$ standard length $\left(L_{S}\right)$, weight $(W)$, Fulton's condition factor (K) of the recaptured grayling.

\begin{tabular}{lcccc}
\hline Group & Number of fish & $L_{s}(\mathrm{~cm})$ & $W(\mathrm{~g})$ & ${ }^{\star} K$ \\
\hline Wild & 79 & $21.3 \pm 1.4^{\mathrm{a}}$ & $123.0 \pm 24.2^{\mathrm{a}}$ & $1.27 \pm 0.17^{\mathrm{a}}$ \\
Pond & 34 & $19.2 \pm 1.0^{\mathrm{b}}$ & $89.3 \pm 15.7^{\mathrm{b}}$ & $1.26 \pm 0.15^{\mathrm{a}}$ \\
Hatchery & 23 & $19.3 \pm 1.1^{\mathrm{b}}$ & $88.0 \pm 17.6^{\mathrm{b}}$ & $1.22 \pm 0.20^{\mathrm{a}}$ \\
\hline
\end{tabular}

Within a column, different superscripts letters indicate a significant difference $(P<0.05)$. $\left.{ }^{*} K=\left(W L_{s}^{-3}\right) \times 100\right)$.

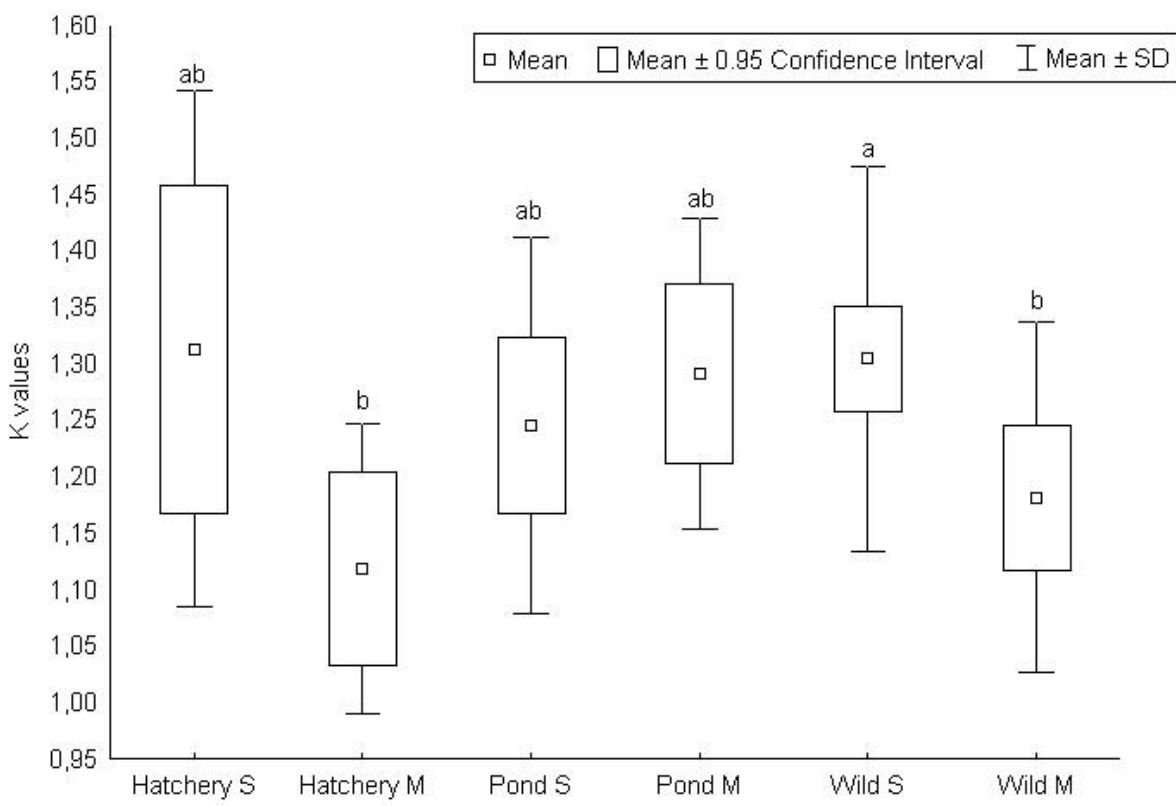

\section{Figure 3}

Relationship between condition factor $(K)$ and origin of fish recaptured in (sedentary-S) and out (migratory-M) of their original section at the end of experiment. Different letter above columns indicate a significant difference $(P<0.05)$.

present study. The higher initial weight was an advantage for wild fish. The effect of individual weight on territorial competition has been demonstrated earlier in brown trout fry (Johnsson et al., 1999). In the present study, the differences in initial weight among wild and reared fish can be explained by lack of natural prey in hatchery fish and/or higher rearing density in artificially reared fish. The influence of rearing method (pond vs. hatchery) on recapture rates of artificially reared fish in this experiment is consistent with some published results (Huet, 1986; Näslund, 1992; Carlstein, 1997). In contrast, Johnsen and Hesthagen (1990) reported that the rearing method is not critical to the recapture rate of stocked brown trout.

Turek et al. (2010a) also found no effect of rearing method on the recapture rate of twoyear-old grayling in the Blanice River. However, in that study the population density of the 
monitored category was doubled. It is possible that the tripled stocking density in the present study led to the differences in recapture rate between artificially reared groups of grayling. Also the age, $1+$ in the present study vs. 2+ in Turek et al. (2010a), could be of importance, suggesting that the 'training' in a pond is more important for younger fish. Higher losses in hatchery-reared fish may also be associated with predation, as otters and herons occur in the study area. Wild and pond fish had been exposed to predators before stocking whereas hatchery fish had no prior experience. Several studies have demonstrated the importance of experience on the development of adequate anti-predator behaviour (e.g. Steward and Bjorn, 1990; Olla et al., 1998). Furthermore, unintentional selection could reduce adaptability of hatchery-reared fish on natural conditions in the present study. The hatchery environment often favours different traits than natural selection in the wild. Therefore, good performance during hatchery rearing may indicate reduced performance in food-limited natural conditions (Saikkonen et al., 2011).

The differences seen in initial mean body weight between wild and both groups of reared fish remained significant until the end of the experiment; however relative weight increase was comparable among all groups. This indicates that hatchery- reared fish were able to learn to feed on natural prey. This could be the result of social learning. Brown and Laland (2001) demonstrated that artificially cultured fish can learn to feed on novel prey by observing a trained conspecific 'demonstrator'. Observed results pointed to competition between stocked and wild fish for territory rather than for food. Sufficient prey for the increased density of fish in the Blanice River after stocking was indicated in other experiments (Turek et al., 2010a, 2010b). However, this cannot be generalized; observations published by Weiss and Schmutz (1999) indicated that abiotic factors in heterogeneous biotopes substantially affected growth of stocked fish. The possible short-term weight loss reported by Thorfve (2002) in stocked grayling was not observed during the 5 months of the present experiment.

Although the condition factor of reared grayling was initially lower, it was equal to that of wild fish at recapture, suggesting that those artificially reared fish that remained in the experimental sections adapted to local conditions. However, adverse effects of the stocking on wild fish were also demonstrated, as their condition factor was lower at the end of the experiment. Observed influence of migration on $K$ values can be explained through higher energy consumption for territorial competition between migratory and resident fish in a new area (Huntingford and De Leaniz, 1997; Rhodes and Quinn, 1998). This strengthens the possibility that habitat competition is one of the primary limiting factors for survival of stocked fish in the Blanice River.

Results of the present study suggest that stocking of artificially reared one-year-old grayling can be used to boost weakening populations of this species. Rearing in a pond was shown to be superior to conventional hatchery rearing for subsequent stocking of $1+$ graylings in running water. However, stocked fish displayed lower recapture and site fidelity compared to wild resident fish. Also an adverse effect of stocking on wild fish was demonstrated. Therefore facilitation of natural spawning should be preferentially practised and supported.

\section{ACKNOWLEDGEMENTS}

This study was supported by the Ministry of Agriculture of the Czech Republic project No. QH71305, by the Grant Agency of the University of South Bohemia No. 047/2010/Z and the project CENAKVA CZ.1.05/2.1.00/01.0024. The authors thank the Czech Anglers' Union for technical support.

\section{REFERENCES}

Arias L., Sanchez L. and Martinez P., 1995. Low stocking incidence in brown trout populations from northwestern Spain monitored by LDH-5* diagnostic markers. J. Fish Biol., 47, 170-176.

Balon E.K., 1962. Age and growth of the spawning shoal of Thymallus thymallus (Linnaeus, 1758) from a riverine lake on the Hnilec River. Zool. Listy, 25, 145-154. 
Brännäs E., 1995. First access to territorial space and exposure to strong predation pressure: a conflict of early emerging Atlantic salmon (Salmo salar L.). Evol. Ecol., 9, 411-420.

Brown C. and Laland K., 2001. Social learning and life skills training for hatchery-reared fish. J. Fish Biol. , 59, 471-493.

Carlstein M., 1997. Effects of rearing technique and fish size on post-stocking feeding, growth and survival of European grayling, Thymallus thymallus (L.). Fish. Manag. Ecol., 4, 391-404.

Carlstein M. and Eriksson L.-O., 1996. Post-stocking dispersal of European grayling, Thymallus thymalIus L., in a seminatural experimental stream. Fish. Manag. Ecol., 3, 143-155.

Cowx I.G., 1994. Stocking strategies. Fish. Manag. Ecol., 1, 15-30.

Ersbak K. and Haase B.L., 1983. Nutritional deprivation after stocking as a mechanism leading to mortality in stream-stocked brook trout. N. Am. J. Fish. Manage., 3, 142-151.

Finstad B., Iversen M. and Sandodden R., 2003. Stress-reducing methods for releases of Atlantic salmon (Salmo salar) smolts in Norway. Aquaculture, 222, 203-214.

Flick W.A. and Webster D.A., 1964. Comparative first year survival and production in wild and domestic strains of brook trout, Salvelinus fontinalis. Am. Fish. Soc., 93, 58-69.

Glova G.J. and Field-Dodgson M.S., 1995. Behavioral interactions between chinook salmon and brown trout juveniles in a simulated stream. Am. Fish. Soc., 124, 194-206.

Huet M., 1986. Textbook of Fish Culture: Breeding and Cultivating of Fish, 2nd edition, Fishing News Books Ltd., Farnham, Surrey, 438 p.

Huntingford F.A. and De Leaniz C.G., 1997. Social dominance, prior residence and the acquisition of profitable feeding sites in juvenile Atlantic salmon. J. Fish Biol., 51, 1009-1014.

Johnsen B.O. and Hesthagen T., 1990. Recapture of pond- and hatchery-reared brown trout, Salmo trutta L., released in small streams. Aquac. Fish. Manag., 21, 245-252.

Johnsen B.O. and Ugedal O., 1986. Feeding by hatchery-reared and wild brown trout, Salmo trutta L., in a Norwegian stream. Aquac. Fish. Manag., 17, 281-287.

Johnsen B.O. and Ugedal O., 1990. Feeding by hatchery- and pond-reared brown trout (Salmo trutta L.), fingerlings released in a lake and in a stream. Aquac. Fish. Manag., 21, 253-258.

Johnsson J.I., Nöbbelin F. and Bohlin T., 1999. Territorial competition among wild brown trout fry: effects of ownership and body size. J. Fish Biol., 54, 469-472.

Jonsson S., Brännäs E. and Lundqvist H., 1999. Stocking of brown trout, Salmo trutta L. effects of acclimatization. Fish. Manag. Ecol., 6, 459-473.

Kaya C.M. and Jeanes E.D., 1995. Retention of adaptive rheotactic behaviour by F1 fluvial Arctic grayling. Am. Fish. Soc., 124, 453-457.

Kenward M.G. and Roger J.H., 1997. Small sample inference for fixed effects from restricted maximum likelihood. Biometrics, 53, 983-997.

Liang K.Y. and Zeger S.L., 1986. Longitudinal data analysis using generalized linear models. Biometrika, 73, 13-22.

Lusk S., 1975. Distribution and growth rate of grayling (Thymallus thymallus) in the drainage area of the Svratka river. Folia Zool. Brno, 24, 385-399.

Magee J.P. and Byorth P.A., 1994. Competitive interactions of fluvial Arctic grayling (Thymallus arcticus) and Brook trout (Salvelinus fontinalis) in the Upper Big Hole River, Montana, Dillon, MT: Montana Department of Fish, Wildlife and Parks, $38 \mathrm{p}$.

Miller R.B., 1954. Comparative survival of wild and hatchery-reared cutthroat trout in a stream. T. Am. Fish. Soc., 83, 120-130.

Näslund I., 1992. Survival and distribution of pond- and hatchery-reared 0+ brown trout, Salmo trutta L., released in a Swedish stream. Aquac. Fish. Manag., 23, 477-488.

Olla B.L., Davis M.W. and Ryer C.H., 1998. Understanding how the hatchery environment represses or promotes the development of behavioral survival skills. Bull. Mar. Sci., 62, 531-550.

Rhodes J.S. and Quinn T.P., 1998. Factors affecting the outcome of territorial contest between hatchery and naturally reared coho salmon parr in the laboratory. J. Fish Biol., 53, 1220-1230.

Saikkonen A., Kekäläinen J. and Piironen J., 2011. Rapid growth of Atlantic salmon juveniles in captivity may indicate poor performance in nature. Biol. Conserv., 144, 2320-2327.

Salonen A. and Peuhkuri N., 2004. A short history: Does it make a difference to aggressiveness in European grayling? J. Fish Biol., 65 (Suppl. A), 231-239. 
Steward C.R. and Bjorn T.C., 1990. Supplementation of salmon and steelhead stocks with hatchery fish: a synthesis of published literature, Tech. Rep. No. 90-1 for The Office of Information Transfer, U.S. Fish and Wildlife Service, Dworshak Fisheries Assistance Office, U.S. Fish and Wildlife Service and Bonneville Power Administration.

Thorfve S., 2002. Impacts of in-stream acclimatization in post-stocking behaviour of European grayling in a Swedish stream. Fish. Manag. Ecol., 9, 253-260

Thorfve S. and Carlstein M., 1998. Post-stocking behaviour of hatchery-reared European grayling (Thymallus thymallus L.) and brown trout (Salmo trutta L.) in a semi-natural stream. Fish. Manag. Ecol., 5, 147-159.

Turek J., Randák T., Horký P., Žlábek V., Velíšek J., Slavík O. and Hanák R., 2010a. Post-release growth and dispersal of pond and hatchery reared European grayling, Thymallus thymallus, compared to their wild conspecifics in a small stream. J. Fish Biol., 76, 684-693.

Turek J., Horký P., Velíšek J., Slavík O., Hanák R. and Randák T., 2010b. Recapture rate and growth of hatchery-reared brown trout (Salmo trutta v. fario, L.) in Blanice River and the effect of stocking on wild brown trout and grayling (Thymallus thymallus, L.). J. Appl. Ichthyol., 26, 881-885.

Vincent R.E., 1960. Some influences of domestication upon three stocks of brook trout (Salvelinus fontinalis Mitchill). Am. Fish. Soc., 89, 35-52.

Weber E.D. and Fausch K.D., 2003. Interactions between hatchery and wild salmonids in streams: differences in biology and evidence for competition. Can. J. Fish. Aquat. Sci., 60, 1018-1036.

Weiss S. and Schmutz S., 1999. Performance of hatchery-reared brown trout and their effects on wild fish in two small Austrian streams. Am. Fish. Soc., 128, 302-316. 